\title{
Integrating sustainability issues into English language courses at university
}

\author{
Nataliya Gunina ${ }^{1, *}$, Tatiana Mordovina ${ }^{1}$, and Irina Shelenkova ${ }^{2}$ \\ ${ }^{1}$ Tambov State Technical University, Tambov, Russia \\ ${ }^{2}$ Istanbul Medipol University, Istanbul, Turkey
}

\begin{abstract}
Education for Sustainable Development is a relatively new methodology that promotes principles of sustainable living and is aimed at integrating sustainability issues into the curriculum at all cycles of formal education. This paper discusses how sustainability development concepts can be taught through English language courses at university. The range of topics that cover sustainable development issues within the framework of key dimensions, such as economy, society, environment and culture is selected in line with the guiding principles of Education for Sustainable Development. The approaches to designing a course in English for undergraduate non-linguistic students through the prism of sustainable development principles are highlighted. It is proposed to develop a syllabus with a focus on the areas that are embedded in the concept of Education for Sustainable Development. These include such topics as gender equality and human rights, sustainable lifestyles, promotion of a culture of peace and non-violence, global citizenship, and appreciation of cultural diversity. The paper summarizes the findings of the research conducted at universities in Russia and Turkey to develop a strategy for designing English language courses that incorporate sustainability issues.
\end{abstract}

\section{Introduction}

One of the ways of promoting sustainability principles is to educate people on the importance of sustainable living for their future. The terms Education for Sustainability (EfS), Education for Sustainable Development (ESD) and Sustainability Education (SE) basically refer to the same concept and are quite often used interchangeably. To avoid confusion we will use the term 'ESD', which is understood as a new educational paradigm encompassing four dimensions - economy, society, environment and culture - that are interrelated and cannot be treated separately. Living in a society, everyone should strive to improve the quality of their life as individuals and as members of the community at the same time. The concepts of sustainability are based on the idea that everyone should get involved with the initiatives that will contribute to sustainable living in their personal lives, within their community and also at a global scale, now and in the future.

The need to raise people's awareness of the environmental problems and to address the most urgent societal issues is of paramount importance, which is why ESD is one of the

*Corresponding author: natalya_gunina@mail.ru 
core elements of the Sustainable Development Goal 4 that focuses on quality education [1]. One of the characteristic features of ESD methodology is its interdisciplinary nature, which means that all aspects of sustainability, including social, economic, environmental and cultural factors can be integrated into the curriculum.

The relevance of the course contents to the SDGs in the university learning context was discussed in a number of studies [2-5]. For example, in [2, 6], the authors focus on general approaches to implementing sustainability in higher education. Some aspects of designing specialized course syllabus on sustainable development in English language teaching were covered in [3,5]. A holistic research framework for the research on sustainable education was proposed in [4]. Since quite a lot of countries have already embarked on a mission of implementing the ESD principles in their educational policies and curricula, it is expedient to investigate the problem from the perspective of designing English language courses incorporating sustainability issues. In this paper, the following questions will be adressed:

- What sustainability-related topics can be added to the English language courses delivered at universities?

- What learning objectives related ESD can be integrated with the existing university curricula?

- What educational tools can be used to achieve the desirable learning outcomes?

Selecting the appropriate content for English language courses is a serious task as most university students want to focus on their industry-related language rather than just study English. When introducing sustainability-related topics, course designers have to bear in mind that it is necessary to balance the students' needs and the relevant content. Another important consideration is the learning objectives, which have to be adjusted to make sure that they are formulated in the right manner and will help students to achieve the learning outcomes. Course designers also have to take into account that the choice of education tools can make a big difference to the course implementation. Project-based learning, collaborative learning, task-based learning are just a few of the instruments that can be used in the English language classroom at university.

\section{Methods and materials}

The research was organized as a study that was based on a questionnaire, the analysis of relevant ESD materials and toolkits, as well as the study of the experience of other universities.

The first step involved conducting the needs analysis survey. To achieve this a questionnaire was developed to find out the students' expectations from the course, and the possibility of integrating sustainability-related topics with the course.

The importance of the needs analysis is manifested in the following definition of the course objectives, which are understood as 'the goals of a course in English, as indicated by the needs analysis, and expressed in terms of what the learner should be able to do' [7 p.221]. This means that needs analysis is a prerequisite for a successful formulation of learning outcomes. It is the most important stage in any course design as it helps to identify what skills and knowledge students need. By analyzing students' needs the course designer can prioritize the goals they want to achieve and make sure the course will help them to fulfill this task. Apart from this, students can reveal their weaknesses and see the gap between what they already know and what they need to learn.

The second step was aimed at formulating the learning objectives in accordance with the students' feedback on the questionnaires. The goal was to specify what specific sustainability knowledge students need to acquire. It was important to make sure that on completion of the course students are equipped with skills and knowledge that they need to deal with challenges of sustainable development both locally and globabally. For the 
accurate formulation of the learning objectives Education for Sustainable Development Goals: Learning Objectives was used as a guide, which is a part of the Global Action Program (GAP) on ESD. This program resulted from the UN Decade on ESD that lasted for 10 years, from 2005 to 2014. The guidelines can be used in different learning context and contain methods for the implementation of the program, learning activities and suggested topics [1].

The third step comprised selecting the activities and educational tools that can be used in the classroom to achieve the learning outcomes. One of the outcomes of the English language course at university is acquisition of transferrable skills and soft skills. These terms basically mean the same, and include the skills and abilities that can be used in different fields. Soft skills are included in transferrable skills and can be defined as personal attributes that enhance an individual's interactions and his/her job performance' [9-11]. Traditionally, university education has been centered around the development of hard skills, which are seen as a primary goal of university training. Yet, communication skills, teamwork, ability to handle stress and manage time efficiently, leadership, problem-solving skills are also of great importance as employers seek candidates who are 'not only are competent in their field of specialization but also possess adequate soft skills' [11].

The research rests on the assumption that teaching sustainability issues at university across the curriculum can improve considerably the development of students' soft skills. Project-based learning seems to be a good teaching method as it is student-centered, involves collaboration and creativity and improves critical thinking and communication skills. Students work together or individually on a challenging and authentic question, they do research and present their findings in a form of presentation. In project-based learning, 'a learning process in which students are engaged in working on authentic projects and the development of products' [12, p.2].

Project-based learning can be supplemented by the collaborative learning, which promotes working together in order to achieve the learning goal. In this approach, work is organized in pairs or small groups and it can be done both in classroom and outside the classroom. The obvious advantage of such an approach is that it involves active participation of all students and engagement with the meaningful content and each other. By doing this students build up their knowledge of key concepts (hard skills) and learn how to interact with each other (soft skills).

Another effective educational tool is Task-Based Learning (TBL), which is method of teaching language through the completion of a certain task. The lesson structure comprises a series of activities aimed at solving a task. This means that the focus is shifted from drilling just grammar and vocabulary to a more authentic use of language. A typical TBL lesson consists of three cycles. The first one is the pre-task stage involves introducing the task and activating the topic-related vocabulary. The second cycle is completion of a communicative task. Students are encouraged to use words and phrases they are familiar with. In the third cycle is language work, where a more detailed analysis of the language structures that emerged during the second cycle is made. If the need occurs, teachers are encouraged to provide more practice activities to fit into the lesson.

The teaching methods mentioned above seem to be well-suited to teach sustainabilityrelated topics in English language classes at university. All of them have the following common features (see Table 1):

- They are learner-centered, the teacher plays the role of a facilitator whose job is to make sure that learning takes place in the appropriate learning environment and provide guidelines and language input. It is not the teacher, but the learner who is in the center of the lesson. 
- Language gradually emerges through various stages of the lesson. All three methods are based on a holistic approach to teaching language by focusing on the function rather than the form.

- Language is used for communication. Students get involved in the lesson as they need to convey a message to the other members of the group in order to find a solution to a problem, or to solve a certain task.

Table 1. Comparison of learning methods for English language courses.

\begin{tabular}{|c|c|c|c|}
\hline $\begin{array}{l}\text { Assessment } \\
\text { Criteria }\end{array}$ & $\begin{array}{l}\text { Project-Based } \\
\text { Learning }\end{array}$ & $\begin{array}{l}\text { Collaborative } \\
\text { Learning }\end{array}$ & $\begin{array}{l}\text { Task-Based } \\
\text { Learning }\end{array}$ \\
\hline $\begin{array}{l}\text { Learning } \\
\text { environment }\end{array}$ & learner-centered & learner-centered & learner-centered \\
\hline Teacher's role & facilitator & facilitator & facilitator \\
\hline $\begin{array}{l}\text { Teaching } \\
\text { methodology }\end{array}$ & holistic & holistic & holistic \\
\hline $\begin{array}{c}\text { Student } \\
\text { engagement }\end{array}$ & high & high & high \\
\hline Duration & $\begin{array}{l}\text { from one lesson to } \\
\text { an academic term }\end{array}$ & $\mathrm{n} / \mathrm{a}$ & a lesson \\
\hline Group size & small groups & any size & $\begin{array}{l}\text { from small groups } \\
\text { to big teams }\end{array}$ \\
\hline Peer-feedback & non-structured & $\begin{array}{l}\text { structured and non- } \\
\text { structured }\end{array}$ & structured \\
\hline
\end{tabular}

\section{Results and discussion}

The needs analysis survey was conducted in September 2020 at two universities - Tambov State Technical University (Tambov, Russia) and Istanbul Medipol University (Istanbul, Turkey). A sample of 600 respondents was selected for the survey. It comprised 345 students from the Russian university and 255 students from the Turkish university. The survey was set up in Google forms and consisted of several questions. The aim was to identify the learners' profile in both universities, to select to topics related to sustainable development for their further integration into the English language courses, to develop strategies for the course design, including its learning objectives and tools for practical implementation. Below is a part of the questionnaire that students had to fill in (Table 2).

Table 2. Learner profile questionnaire (sample).

\begin{tabular}{|l|l|l|}
\hline Personal details (optional) & & \\
\hline Gender & & \\
\hline Age & & \\
\hline Number of years learning & & \\
English & & \\
\hline Specialization & \\
\hline
\end{tabular}

The survey showed that the respondents were enrolled in the following programs: Architecture, Finance and Economics and Law. The distribution of the respondents is given in Fig. 1. 


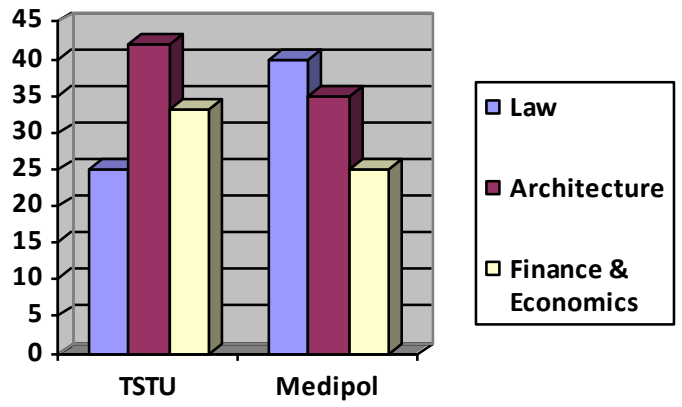

Fig.1. Distribution of the respondents at both universities by specialization.

The survey was conducted by the method of random sampling; students were selected from three departments at both universities.

\subsection{Selecting sustainability-related topics}

The second section on the students' questionnaire contained two questions: the first question concerned the choice of topics for study, and the second one - the expected learning outcomes. We consider each question and analyze the answers to them separately.

Table 3. Learners' questionnaire on the choice of topics to study.

\begin{tabular}{|l|l|}
\hline 1. Mark $\mathbf{5}$ most interesting topics by checking the box next to the topic: & $\checkmark$ \\
\hline 1. Ending poverty in all its forms. & \\
\hline 2. Problems of food security and better quality of nutrition. & \\
\hline 3. Good health and healthy living. & \\
\hline 4. Quality education and lifelong learning opportunities for all. & \\
\hline 5. Ways of preventing gender inequality. & \\
\hline 6. Expanding access to clean drinking water. & \\
\hline 7. Economic growth, full employment and decent work. & \\
\hline 8. Dealing with inequality. & \\
\hline 9. Responsible conservation and management of marine resources. & \\
\hline 10. Responsible consumption and production. & \\
\hline 11. Climate change and its impacts. & \\
\hline 12. Protection of ecosystems. & \\
\hline 13. Access to justice for all. & \\
\hline 14. Global networking for sustainable development. & \\
\hline 15. Sustainable cities and settlements. & \\
\hline
\end{tabular}

The students were supposed to select the topics that might be of interest to them (see Table 3). The list of topics was compiled using UNESCO Education for Sustainable Development Guide [1]. The results of the survey were summarized in two diagrams (see Figs. 2 and 3). 


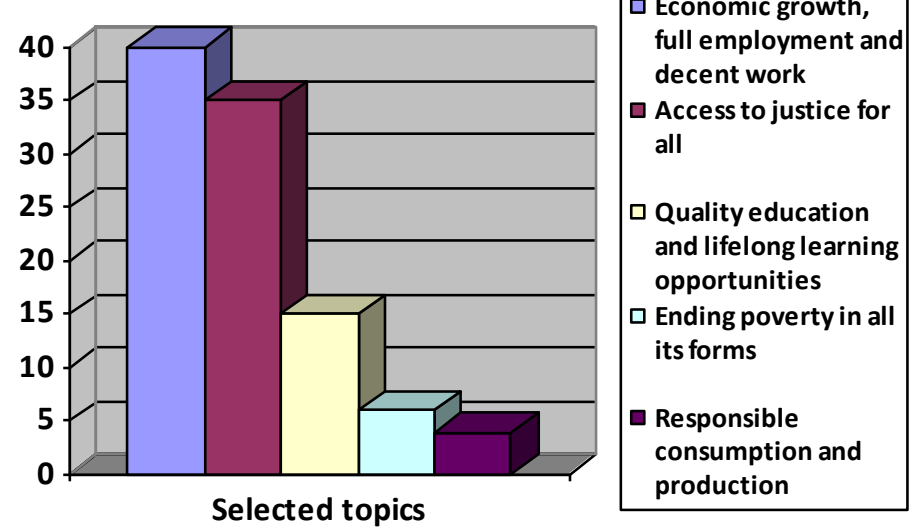

Fig.2. Sustainability-related topics selected by the students from the Russian university.

Interestingly, the most popular topics for the Russian students were Economic growth, full employment and decent work (40\%) and Access to justice for all (35\%), respectively. The other three were Quality education and lifelong learning opportunities for all (15\%), Poverty in all its forms (6\%), and Responsible consumption and production (4\%).

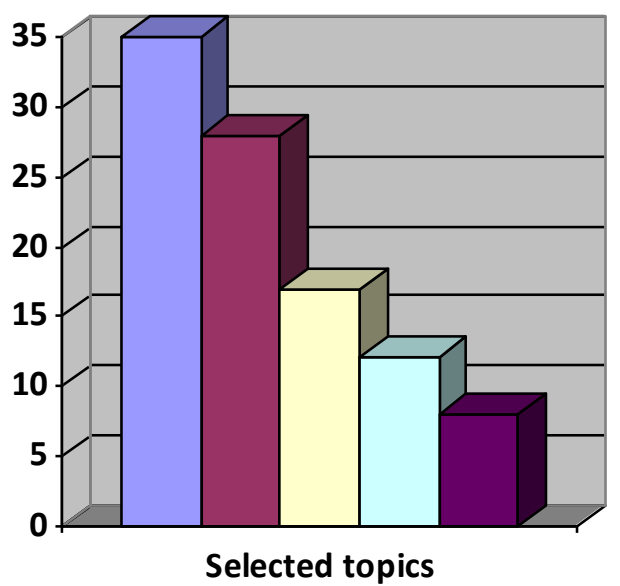

\begin{tabular}{|l|}
\hline \\
Access to justice \\
for all \\
\\
Quality education \\
and lifelong \\
learning \\
opportunities \\
Responsible \\
consumption and \\
production \\
$\square$ Economic growth, \\
full employment \\
and decent work \\
$\square$ Climate change \\
and its impacts \\
\hline
\end{tabular}

Fig.3. Sustainability-related topics selected by the students from the Turkish university.

The most relevant topics for the Turkish students were Access to justice for all (35\%) and Quality education and lifelong learning opportunities for all (28\%). The other three were Responsible consumption and production (17\%), Economic growth, full employment and decent work (12\%) and Climate change and its impacts (8\%).

As you can see from the diagrams, four of the topics chosen by the students of both universities were the same, with the topic Access to justice for all being of interest to the same number of students from both countries. 


\subsection{Learning objectives for English courses with a focus on ustainable development}

The survey findings were used to define the learning objectives for each of the topics chosen by the students of both universities.

All learning objectives are described from three different perspectives: cognitive, socioemotional and behavioral. The cognitive perspective is related to skills and abilities necessary for acquiring content referring to each topic. The socio-emotional perspective focuses on the development of interpersonal skills as well as self-reflection skills. The behavioral perspective deals with the ability of learners to take actions that may help to solve societal problems [1]. The learning objectives are summarized in Table 5.

Table 4. Learning objectives for sustainable development goals.

\begin{tabular}{|c|c|c|}
\hline \multicolumn{3}{|c|}{ Ending poverty in all its forms } \\
\hline cognitive & socio-emotional & behavioral \\
\hline $\begin{array}{l}\text { The learner understands: } \\
\text { - the concepts of poverty and has } \\
\text { their own views on its causes and } \\
\text { consequences; } \\
\text { - } \\
\text { - how poverty relates to human } \\
\text { rights. }\end{array}$ & $\begin{array}{l}\text { The learner is able to: } \\
\text { - research the facts about poverty } \\
\text { and propose their own solution to } \\
\text { the problem; } \\
\text { - show empathy for poor people; } \\
\text { - realize their own role in the } \\
\text { world of inequality. }\end{array}$ & $\begin{array}{l}\text { The learner is able to: } \\
\text { - plan, evaluate and implement } \\
\text { activities that contribute to } \\
\text { poverty reduction; } \\
\text { - take part in the decision of } \\
\text { local governments in the issues } \\
\text { of poverty eradication; } \\
\text { - propose solutions to address } \\
\text { problems related to poverty. }\end{array}$ \\
\hline \multicolumn{3}{|c|}{ Quality education and lifelong learning opportunities for all } \\
\hline cognitive & socio-emotional & behavioral \\
\hline $\begin{array}{l}\text { The learner understands: } \\
\text { - the importance of education } \\
\text { and the need for lifelong learning } \\
\text { opportunities; } \\
\text { - the importance of equal } \\
\text { opportunities in obtaining quality } \\
\text { education; } \\
\text { - that education can help create a } \\
\text { more sustainable and peaceful } \\
\text { world. }\end{array}$ & $\begin{array}{l}\text { The learner is able to: } \\
\text { - realize the importance of quality } \\
\text { education for all; } \\
\text { - identify their own needs for } \\
\text { personal development and quality } \\
\text { education; } \\
\text { - recognize the need to acquire } \\
\text { new skills to improve the quality } \\
\text { of their own life. }\end{array}$ & $\begin{array}{l}\text { The learner is able to: } \\
\text { - advocate for gender education } \\
\text { equality; } \\
\text { - promote the empowerment of } \\
\text { young people; } \\
\text { - engage in lifelong learning, } \\
\text { without missing any opportunity } \\
\text { and apply the knowledge gained } \\
\text { in life. }\end{array}$ \\
\hline \multicolumn{3}{|c|}{ Economic growth, full employment and decent work } \\
\hline cognitive & socio-emotional & behavioral \\
\hline $\begin{array}{l}\text { The learner understands: } \\
\text { - the concepts of sustainable } \\
\text { economic growth, full } \\
\text { employment and decent work; } \\
\text { - the relationship between } \\
\text { employment and economic } \\
\text { growth. }\end{array}$ & $\begin{array}{l}\text { The learner is able to: } \\
\text { - discuss various economic issues; } \\
\text { - define their own economic } \\
\text { rights, values and needs; } \\
\text { - develop a plan for their own } \\
\text { economic life. }\end{array}$ & $\begin{array}{l}\text { The learner is able to: } \\
\text { - find out facts about sustainable } \\
\text { economic models and have their } \\
\text { own definition of decent work; } \\
\text { - develop and evaluate ideas for } \\
\text { entrepreneurship; } \\
\text { - plan and implement } \\
\text { entrepreneurial projects. }\end{array}$ \\
\hline \multicolumn{3}{|c|}{ Responsible consumption and production } \\
\hline cognitive & socio-emotional & behavioral \\
\hline $\begin{array}{l}\text { The learner understands: } \\
\text { - how the economic development } \\
\text { of a country is influenced by the } \\
\text { lifestyle of an individual; } \\
\text { - how responsibilities and rights } \\
\text { are distributed between the } \\
\text { subjects of consumption and } \\
\text { production. }\end{array}$ & $\begin{array}{l}\text { The learner is able to: } \\
\text { - talk about production and } \\
\text { consumption; } \\
\text { - determine their own desires and } \\
\text { needs, have an idea of their } \\
\text { consumer behavior; } \\
\text { - be responsible for the } \\
\text { consequences of their consumer } \\
\text { behavior. }\end{array}$ & $\begin{array}{l}\text { The learner is able to: } \\
\text { - plan, implement and evaluate } \\
\text { their activities as a consumer; } \\
\text { - promote sustainable production } \\
\text { patterns; } \\
\text { - justify their social and cultural } \\
\text { orientation in production and/or } \\
\text { consumption. }\end{array}$ \\
\hline
\end{tabular}




\begin{tabular}{|c|c|c|}
\hline \multicolumn{3}{|c|}{ Climate change and its impacts } \\
\hline cognitive & socio-emotional & behavioral \\
\hline $\begin{array}{l}\text { The learner understands: } \\
\text { - such a natural phenomenon as } \\
\text { the greenhouse effect; } \\
\text { - which human activities } \\
\text { contribute most to climate } \\
\text { change; } \\
\text { - the main ecological } \\
\text { consequences of climate change } \\
\text { locally and globally. }\end{array}$ & $\begin{array}{l}\text { The learner is able to: } \\
\text { - explain the impact of climate } \\
\text { change on the environment; } \\
\text { - encourage others to protect the } \\
\text { climate; } \\
\text { - be aware of their own role in } \\
\text { changing the global climate from } \\
\text { a local or global point of view. }\end{array}$ & $\begin{array}{l}\text { The learner is able to: } \\
\text { - evaluate your activities in } \\
\text { improving the climate from a } \\
\text { personal and professional point } \\
\text { of view; } \\
\text { - promote climate-protecting } \\
\text { public policies; } \\
\text { - support climate-friendly } \\
\text { economic activities. }\end{array}$ \\
\hline \multicolumn{3}{|c|}{ Access to justice for all } \\
\hline cognitive & socio-emotional & behavioral \\
\hline $\begin{array}{l}\text { The learner understands: } \\
\text { - the concept of justice and law- } \\
\text { abidingness; } \\
\text { - their local and national } \\
\text { legislative systems and is able to } \\
\text { compare it with those of other } \\
\text { countries; } \\
\text { - the role of human rights in the } \\
\text { international system of } \\
\text { relationships. }\end{array}$ & $\begin{array}{l}\text { The learner is able to: } \\
\text { - discuss the main legislative } \\
\text { issues; } \\
\text { - express solidarity and help those } \\
\text { who have been subjected to unfair } \\
\text { justice; } \\
\text { - have their own idea of access to } \\
\text { justice for individuals of various } \\
\text { economic, social, political and } \\
\text { gender groups. }\end{array}$ & $\begin{array}{l}\text { The learner is able to: } \\
\text { - have their own point of view on } \\
\text { issues of fair justice; } \\
\text { - help those groups that are } \\
\text { experiencing a conflict situation } \\
\text { related to justice; } \\
\text { - speak out against injustice by } \\
\text { taking part in settlement } \\
\text { processes and decision-making. }\end{array}$ \\
\hline
\end{tabular}

\subsection{Activities for English classes to achieve the learning objectives}

The aim of any course is to develop a set of competencies that will be useful for the learners when solving both professional and everyday problems. By integrating sustainability issues into the English language course teachers can help their students to acquire a number of competencies, such as anticipatory competency, collaboration competency, systems thinking competency, strategic competency, critical thinking competency, and self-awareness competency.

Anticipatory competency is the ability to develop a certain vision for the future and to evaluate the consequences of your actions. This competency can be developed in the English classroom when students reflect on the problem, estimate possible risks and make informed decisions. For example, as part of task-based learning

Collaboration competency is the ability to work together, be able to support others and show empathy, be able to solve problems and resolve conflicts. This can be done by offering students a number of activities that involve interaction and communication in order to achieve common goals.

Critical thinking competency is the ability to analyze and reflect on your own actions and actions of other people, understand the logical connections and engage in independent thinking. The formation of students' speech activity presupposes the ability to analyze, compare facts and deduce value judgments in written and oral form.

Systems thinking competency is the ability to deal with complex systems, to understand how these systems are connected with each other and to see the big picture of the problem.

Strategic competency is the ability to work together on innovative solutions and take innovative actions.

Self-awareness competency is the ability to assess you role in the community and to motivate oneself to take further action.

For each of the topics selected for the English course, it is expedient to have a list of questions that can be discussed in class. For example, for Economic growth, full employment and decent work the following topics can be suggested:

- What is economic growth? And why is it so important? 
- The reality of people's material living conditions around the world

- What is full employment and what is unemployment

- What makes decent work?

- What is economic ethics?

One of the activities that that can be done in the university learning context within the framework of the abovementioned sustainable development goal is "An enquiry-based project: What can my career contribute to sustainable development. This type of project can be organized for a group of students in order to make their learning more meaningful. It involves serious investigation of the problem, with lots of collaboration, resulting in creation of knowledge. In order to complete the study, students have to make use of their self-management skills, communication skills, problem solving, presentation skills and project management skills. Besides students have to use technology for accomplishing the task. They do research using digital tools and resources in a purposeful manner. As part of the project students have to formulate the research question and collect the necessary data, they need to select the tools for accomplishing their research.

For the topic "Ending poverty in all its forms", the following problems can be incorporated in the class activities:

- Poverty and richness corrupt people's souls

- Poverty prevents people's happiness

- Poverty causes increase in crime

- In a world of wealth, poverty has become a necessity

- Sweatshops, child labor and modern slavery

A sample activity for an English class at university might be a lesson arranged as a game where students are divided into teams and do the quiz on Sweatshops, child labor and modern slavery. The teacher prepares handouts with questions that are either facts or myths about the topic under discussion. Each question has a point value. The students from each team select a question, discuss it and then present their answer to the class. The questions might include:

- Sweatshops are legal in your country.

- Victims of human trafficking are always illegal immigrants.

- There are more people in slavery now than at any other time in human history.

- Many big businesses use child labor.

- Human trafficking is the 2nd largest criminal industry in the world.

- The cost of slave labor has decreased over time.

- Most slavery victims are women and children.

- Trafficking and slavery victims are always poor and uneducated.

- Human trafficking only occurs in illegal, underground industries.

- Most sweatshops are in Europe.

Students have to decide whether the statement is a myth or a fact and provide good reasoning to support their position. This activity involves a great deal of student engagement and collaboration. Students have to use their critical thinking skills in order to make good judgment.

For the topic Quality education and lifelong learning opportunities for all it is suggested to tackle the following problems:

- Do universities offer high quality education?

- Is lifelong learning necessary?

- Benefits of lifelong learning.

- Equality of educational opportunities

An activity that can be used in the classroom is planning a project on promoting ESD at university. Students work in groups and select the problem for their campaign. These can range from inclusive education and access to high quality education in deprived countries, 
gender inequality issues to importance of lifelong learning and skills for the 21 st century. They make a plan and design the stage of their campaign. Then they give a presentation of their ESD campaign and other students assess their work using the assessment criteria grid. For Climate change and its impacts it is suggested to include the following topics:

- The impact of sea level rise on countries (e.g. small island states)

- Greenhouse effect;

- Global warming;

- Ways of protecting the climate;

- Ethics and climate change;

- Assessing the risk and preventing natural disasters.

An activity for the English class is a mini-debate on the topic "Climate Change: Causes and Consequences". Students work in groups of three where each one is assigned a role of a moderator, who listens to both sides of the debate, asks questions, evaluates the arguments presented and gives preference to the one who turned out to be more convincing, a representative of those who believe that climate change is a serious global problem, and a representative of those who do not consider climate change a serious global problem. Students' arguments should be formulated in terms of environment, society and economy (Three Pillars of Sustainability).

\section{Conclusion}

The study contributed to the research into ESD and proposed some ways of dealing with the problem of incorporating sustainability issues into the English language courses. It is important to bear in mind that reorienting a curriculum in ESD requires a combination of a holistic approach and an interdisciplinary approach. At the same time it is necessary to align students' learning objectives and the content of the course.

The research conducted in two universities was focused on exploring students' needs and expectations and possibility of adding sustainability-related topics to the English course syllabus. The findings showed that the students are interested in studying such topics as Economic growth, full employment and decent work, Access to justice for all, Quality education and lifelong learning opportunities for all Ending poverty in all its forms, Responsible consumption and production, Climate change and its impacts. The learning outcomes were formulated for the selected topics in cognitive, socio-emotional and behavioral domains. Sample activities for English classes at university were suggested and described.

\section{References}

1. Education for Sustainable Development Goals: Learning Objectives (UNESCO, 2017)

2. W Leal Filho, A.L. Salvia, R.W. Pretorius, Brandli, L.L. E.Manolas, F. Alves, U. Azeiteiro, J. Rogers, C. Shiel, A. Do Paco, Universities as Living Labs for Sustainable Development: Suporting the Implementation of the Sustainable Development Goals ( Springer, 2020)

3. L. Yılmaz Findık, 'I. Bayram, Ö. Canaran, Int. J. Sustain. High. Educ., 22, 423 (2021)

4. J. Fedosejeva, A. Bo`ce, M.Romanova, D.Iliško, O. Ivanova, J. Teach. Educ. Sustain., 20, 157(2018)

5. C.T.T. Kwee, Teaching. Sustainability, 13, 4195 (2021)

6. J. Marcus, N.C. Coops, Sh. Ellis, J. Robinson, Current Opinion in Environmental Sustainability, 16, 7 (2015)

7. M. Ellis, Ch. Johnson, Teaching Business English (Oxford University Press, 1994) 
8. C. Mcgibbon, J.-P.Van Belle, Current Opinion in Environmental Sustainability 16, 84 (2015)

9. Hendarman A. F., Tjakraatmadja J.H. Procedia - Social and Behavioral Sciences, 52, 35 (2012)

10. M. Debnath, M. Pandey, N. Chaplot, M. R. Gottimukkula, P. K. Tiwari, S. N. Gupta, Enhancing Learning and Teaching Through Student Feedback in Engineering (Chandos Publishing, 2012)

11. G. Hillmer, Int. Conf. Eng. Education (ICEE) (2007)

12. P. Guo, N. Saab, L. S. Post, W. Admiraal, Int. J. of Educational Research, 102, 101586 (2020)

13. A. Maley, N. Peachey Integrating global issues in the creative English language classroom: With reference to the United Nations Sustainable Development Goals (British Council London, 2017) 